Elżbieta Tarkowska

Akademia Pedagogiki Specjalnej im. Marii Grzegorzewskiej, Warszawa

\title{
BIEDNI O POLITYKACH
}

\section{WPROWADZENIE}

Wielisława Warzywoda-Kruszyńska wielokrotnie w swych pracach poruszała kwestię nieobecności problemu ubóstwa w dyskursie publicznym, a w szczególności w dyskursie politycznym w Polsce. Jedną z pierwszych książek na temat ubóstwa, powstałą w łódzkim środowisku socjologicznym, czyli Wielkomiejska biede w okresie transformacji, pióra Wielisławy WarzywodyKruszyńskiej i Jolanty Grotowskiej-Leder (1996) otwiera tekst pierwszej z autorek, charakterystycznie zatytułowany: Bieda - temat wyparty z dyskursu politycznego. Autorka opisuje to zjawisko w szerszym kontekście praktyk minimalizowania i przemilczania problemu biedy w świecie współczesnym zarówno w krajach zachodnich, jak i w krajach postkomunistycznych. Wskazuje na generalny problem istnienia sił politycznych zainteresowanych marginalizacją i przemilczaniem problemu ubóstwa $\mathrm{z}$ jednej strony, $\mathrm{z}$ drugiej - na brak zorganizowania ludzi biednych i wynikającą stąd ich niemożność wywierania odpowiedniego nacisku, co $\mathrm{w}$ rezultacie prowadzi do odpolitycznienia problemu ubóstwa i do jego marginalizacji w postaci ujmowania go jako ,przejściowych trudności”, jako jednostkowego problemu poszczególnych ludzi. W krajach byłego obozu socjalistycznego przemilczanie problemu ubóstwa ma własne źródła, związane z dziedzictwem przeszłości i z niechęcią z jednej strony elit postkomunistycznych do negacji zasad i efektów systemu socjalistycznego, a ze strony postsolidarnościowej - z powstrzymywaniem się przed krytyką procesu transformacji (Warzywoda-Kruszyńska 1996, s. 17-19). Do tego tematu Wielisława Warzywoda-Kruszyńska wróciła po kilkunastu latach opisując wpływ wstąpienia Polski do Unii Europejskiej na pojawienie się pewnych tematów związanych z ubóstwem i wykluczeniem społecznym w dyskursie publicznym i wskazując takie nowe tematy, jak wcześniej przemilczane ubóstwo dzieci, jak stopniowe upowszechnianie się postrzegania biedy jako problemu społecznego, a nie jednostkowego czy jak powstawanie nowej wizji polityki społecznej (Warzywoda-Kruszyńska 2009: 143 i n.). 
Niniejszy tekst dotyczy również ubóstwa i polityki, wszelako ujętych z innego punktu widzenia, niż patrzy nań W. Warzywoda-Kruszyńska, a mianowicie z perspektywy ludzi, którzy obecnie lub w przeszłości doświadczyli ubóstwa. Ich spojrzenie na polityków i na dyskurs polityczny okazało się w pewnym zakresie zbieżne z wnioskami M. Daneckiej, zawartymi w przeprowadzonej przez nią przed kilku laty analizie wypowiedzi na temat ubóstwa i wykluczenia społecznego przedstawicieli elity władzy i innych ważnych osobistości życia publicznego. Część z nich uważała, że „tak naprawdę problemy społeczne, w tym bieda i bezrobocie, nie mają większego znaczenia w kręgach elity władzy i nie istnieje prawdziwa debata na temat ich rozwiązywania" (Danecka 2007: 149). Zacytowana przez tę autorkę sarkastyczna wypowiedź W. Osiatyńskiego w wywiadzie udzielonym „Gazecie Wyborczej” dobrze oddaje punkt widzenia uczestników moich badań i mogłaby pełnić funkcję motta niniejszego tekstu: „polska klasa polityczna jest inteligentna, ale głównie w trosce o własne interesy” (Osiatyński 2004).

Podstawą empiryczną niniejszego tekstu są wyniki badania „Biedni o sobie”, przeprowadzonego w $2011 \mathrm{r}$. w ramach projektu badawczego „Dyskursy ubóstwa i wykluczenia społecznego" 1 . Fragment tego badania dotyczył polityki i wizerunku polityków w kontekście problemów ubóstwa i wykluczenia społecznego. Uczestnicy badania łączyli politykę z mediami, dostrzegając w obu tych sferach podobne mechanizmy, co też zostało uwzględnione w niniejszym tekście.

\section{KILKA SŁÓW O BADANIU „BIEDNI O SOBIE”}

Badanie „Biedni o sobie” polegało na zogniskowanych wokół problemu biedy i jej wizerunków dyskusjach grupowych ludzi, którzy sami doświadczyli ubóstwa w przeszłości lub obecnie go doświadczają. Celem badania było poznanie wyobrażeń, koncepcji i opinii tych ludzi na temat ubóstwa i jego różnych aspektów. Scenariusz wywiadu zawierał trzy grupy problemów: pierwszy kompleks pytań i problemów odnosił się do koncepcji, wyobrażeń, sposobów rozumienia ubóstwa, jego uwarunkowań i konsekwencji, a więc na przykład tego, jak ludzie stają się biednymi, kto to jest człowiek biedny, jak ludzie radzą

${ }^{1}$ Był to projekt badawczy „Dyskursy ubóstwa i wykluczenia społecznego” nr NN 116274738 , kierowany przez E. Tarkowską, sfinansowany przez Ministerstwo Nauki i Szkolnictwa Wyższego (a następnie przez Narodowe Centrum Nauki). Badanie „Biedni o sobie” zostało najpełniej przedstawione w tekście pt. Biedni o biedzie, biedni o sobie w książce pod redakcją E. Tarkowskiej Dyskursy ubóstwa i wykluczenia społecznego (2013). Niniejszy tekst jest przedstawieniem niewielkiego fragmentu przeprowadzonych badań. 
sobie z biedą, jak z niej wychodzą itd. Drugi zestaw pytań i tematów do dyskusji dotyczył tego, co R. Lister nazywa relacyjno-symbolicznymi aspektami ubóstwa, czyli tego, jak zdaniem badanych ludzie biedni są postrzegani i traktowani przez tych, którzy nie znają biedy z własnego doświadczenia. Były to więc takie kwestie i pytania, jak: Na czyją pomoc może liczyć człowiek żyjący w biedzie? Jak ludzie bogaci traktują biednych? Jak do biednych odnoszą się instytucje, takie jak pomoc społeczna, organizacje charytatywne, szkoła, Kościół, media? Wśród licznych przedstawicieli świata zewnętrznego wobec ubóstwa (urzędników, pracowników socjalnych, nauczycieli, księży, pracowników służby zdrowia, policji) wymieniono również polityków. Celem tego fragmentu wymiany poglądów była realizacja drugiego głównego zadania badawczego, czyli rekonstrukcja relacji otoczenia zarówno instytucjonalnego, jak i jednostkowego z ludźmi żyjącymi w biedzie, tak jak to widzą oni sami na podstawie własnych doświadczeń. Trzecia część dyskusji dotyczyła interpretacji pewnych autentycznych wydarzeń, takich jak tragiczny wypadek zatłoczonego mikrobusu, dowożącego pracowników sezonowych do pracy, gdy zginęło osiemnastu ludzi, czy jak mieszkania socjalne dla biednych ulokowane na peryferiach. Ujawniały one nie tylko drastyczne aspekty życia w biedzie, ale przede wszystkim pokazywały skrajne reakcje i postawy wobec ubóstwa i ludzi biednych ze strony przedstawicieli różnych instytucji. Celem tego bloku tematów było pogłębienie i konkretyzacja wcześniej poruszanych zagadnień z kręgu relacyjno-symbolicznych aspektów ubóstwa.

W ramach badania przeprowadzono trzy zogniskowane wywiady w trzech odmiennych grupach. Ich profil i skład wiązał się z charakterystycznymi cechami biedy w Polsce. Uczestniczkami pierwszej grupy (FG1) było dziesięć kobiet - matek ze wsi popegeerowskiej w województwie warmińsko-mazurskim, w szerokim przedziale wieku (23-55 lat), które obecnie, lub w przeszłości, korzystały z pomocy społecznej. Druga grupa (FG2) składała się z ośmiu młodych osób, kobiet i mężczyzn, w wieku 20-24 lata, mieszkających na wsi w okolicach małego miasta powiatowego, w centralnej Polsce. Były to osoby niepracujące i nieuczące się, pochodzące z rodzin korzystających z pomocy społecznej. W skład trzeciej grupy (FG3) weszło pięć kobiet i pięciu mężczyzn, mieszkańców miasta średniej wielkości w centralnej Polsce, w zróżnicowanym wieku (od 29 do 60 lat) i o zróżnicowanej sytuacji rodzinnej. Łączyła ich skrajna bieda (z bezdomnością włącznie), długotrwałe bądź chroniczne wykluczenie z rynku pracy oraz wieloletnie kontakty z instytucjami pomocy społecznej.

Zastosowany we wszystkich trzech przypadkach jednakowy scenariusz wywiadu doprowadził do zróżnicowanych odpowiedzi, co w wypadku zogniskowanych wywiadów grupowych nie jest czymś niezwykłym. Główne wątki 
rozmowy potoczyły się w różnych kierunkach, związanych z odmiennymi doświadczeniami poszczególnych kategorii rozmówców, z odmiennymi problemami, z jakimi się obecnie borykają, w tym ze zróżnicowanym poziomem deprywacji oraz charakteru i głębokości wykluczenia, w jakim żyją. Pod tym względem w najlepszej sytuacji znajdowali się uczestnicy grupy młodzieży, mimo braku pracy i braku perspektyw, w stosunkowo niezłej była grupa kobiet, które odmówiły tożsamości osób biednych i same określiły się jako „mniej zamożne”, a z ich wypowiedzi wyłaniał się przejściowy charakter zdarzających się sytuacji braku pracy, zmuszających do korzystania z pomocy społecznej. W najgorszej sytuacji skumulowanego wykluczenia i długotrwałego bezrobocia oraz wieloletnich kontaktów z instytucjami pomocy społecznej znajdowali się członkowie grupy bezrobotnych. To zróżnicowanie przekładało się na zakres i charakter wprowadzanych przez samych rozmówców tematów do dyskusji². I tak, dla kobiet - matek rodzin ważne okazały się bezpośrednie skutki biedy dla życia rodzinnego, prowadzące niekiedy do rozpadu związku, szczególna odpowiedzialność kobiet za funkcjonowanie rodziny w warunkach ubóstwa, trudności znalezienia pracy przez kobiety wychowujące dzieci oraz troska o przyszłość dzieci (FG1). Dla ludzi młodych najważniejsze okazały się problemy rynku pracy, różnice między płciami oraz kwestie relacyjne zarówno godnościowe, jak i prestiżowe (FG2). Grupa uczestników połączonych doświadczeniem długotrwałego (na ogół) bezrobocia i niskopłatnej pracy (FG3) miała dużo do powiedzenia o utracie pracy i niemożności znalezienia nowej, o fatalnym rynku pracy w Polsce oraz o słabości czy wręcz niedowładzie instytucji, które powinny świadczyć biednym pomoc z racji ich zadań ustawowych (miejski ośrodek pomocy społecznej, powiatowy urząd pracy) lub z racji misji (Kościół, organizacje społeczne o profilu charytatywnym, takie jak Caritas). Innym istotnym wątkiem w tej dyskusji była izolacja społeczna ludzi biednych jako jedna z bardziej dotkliwych konsekwencji ubóstwa.

Wszyscy uczestnicy dyskusji odwoływali się do własnych doświadczeń, niekiedy bardzo trudnych, przywoływali przykłady z własnego życia, opowiadali o licznych, niekiedy wieloletnich kontaktach z instytucjami pomocy społecznej. Dyskusje grupowe pokazały doniosłą rolę własnego doświadczenia w postrzeganiu i interpretacji biedy oraz w postrzeganiu relacji między ludźmi znajdującymi się w trudnej sytuacji ekonomicznej a światem zewnętrznym.

${ }^{2}$ Badacze dyskusji grupowych wyodrębniają tematy zaproponowane przez moderatora (makrotematy według R. Wodak, tematy prymarne w ujęciu M. Krzyżanowskiego) oraz tematy wprowadzone w toku dyskusji przez uczestników, oddolnie (sekundarne według Krzyżanowskiego) (por. Wodak 2011; Krzyżanowski 2011). To one w znacznej mierze są ,odpowiedzialne” za różnorodność tematyczną dyskusji. 


\section{RELACYJNY WYMIAR UBÓSTWA}

W omawianych badaniach sprawą najbardziej interesującą z metodologicznego punktu widzenia jest, z jednej strony, różnorodność wątków pojawiających się w dyskusjach oraz wielość tematów oddolnych, wprowadzonych przez uczestników poszczególnych grup do zbiorowej debaty, a z drugiej strony powtarzalność pewnych wątków i tematów. Tragiczna katastrofa mikrobusu doprowadziła $\mathrm{w}$ jednej grupie do refleksji na temat nierówności, nawet w obliczu śmierci, ludzi biednych (katastrofa mikrobusu) i bogatych (katastrofa samolotu prezydenckiego pod Smoleńskiem), a w innej grupie do niesprawiedliwego traktowania dzieci z biednych rodzin $\mathrm{w}$ szkole. $\mathrm{Z}$ kolei temat feminizacji ubóstwa i specyficznych trudności kobiet na rynku pracy powracał w różnych momentach dyskusji w poszczególnych grupach, podobnie jak krytyka niskiej jakości pomocy udzielanej przez instytucje. Najbardziej spektakularnym przykładem odrębności, a jednocześnie powtarzalności podejmowanych wątków są wypowiedzi, zainspirowane pytaniem moderatora o najtrudniejsze doświadczenie w życiu człowieka biednego. Dla grupy kobiet (FG1) czymś najtrudniejszym okazał się brak perspektywy przyszłości, niepewność i niepokój o przyszłość, spowodowany głównie troską o dzieci: „Najgorsze jest to, że człowiek nie czuje tej perspektywy (R1/FG133); „To jest takie przerażające. Człowiek nie wie, co będzie jutro. Brak pewności. Strach przed tym, co przyniesie jutrzejszy dzień" (R10/FG1); „Tak samo boję się, co przyniesie jutro [...] Strach. Człowiek się uczy dalej i coś chce zrobić, ale i tak w punkcie stoi” (R5/FG1). „Obawa wobec jutra, troska o codzienność", to w świetle wypowiedzi uczestników omawianych badań najbardziej charakterystyczny rys życia w biedzie. Temat ten pojawiał się w różnych momentach grupowych dyskusji, w pytaniu o najtrudniejsze doświadczenie życia w biedzie zabrzmiał szczególnie mocno w wypowiedziach uczestniczek grupy pierwszej.

Na to samo pytanie w dwu pozostałych grupach, obejmujących ludzi młodych (FG2) oraz osoby długotrwale bezrobotne (FG3), odpowiedziano zupełnie inaczej, pracowników. Wyrażały to wielotysięczne akcje protestacyjne organizowane bardzo zbliżony do siebie sposób. Najtrudniejszym doświadczeniem w życiu ludzi biednych jest, zdaniem grupy młodych ludzi, sposób odnoszenia się do nich ludzi spoza świata biedy: „Ci bogaci. Poniżanie przez innych, wyższych tak zwanych” (RB/FG2); „Może nie tyle aż, ale wyśmiewanie się” (RC/FG2); „Bo to siada bardzo na psychikę” (RB/FG2); „Czyli jednak reakcje

${ }^{3}$ Symbol oznacza rozmówcę i grupę dyskusyjną. W wszystkich cytatach zachowano oryginalną składnię i styl wypowiedzi uczestników. 
innych osób są najtrudniejsze w tym wszystkim?” [moderator] „Tak” (RA/FG2, $\mathrm{RH} / \mathrm{FG} 2)$; „Takie osoby popadają w apatię i stopniowo to jest równia pochyła w dół. Czyli nawet jeśli chcą się wyrwać, to co z tego, jak są dobijani do gleby" (RA/FG2); „No, raczej tak. To jest bardzo ważne, żeby psychikę mieć normalną, a nie poniżanym być przez kogoś" (RE/FG2).

Podobnie odpowiedzieli uczestnicy trzeciej grupy, osoby długotrwale wykluczone z rynku pracy, żyjące w skrajnej biedzie, a nawet zmagające się z bezdomnością: „Że każdy ma nas gdzieś” (Rg/FG3); „Poniżanie człowieka” (Re/FG3); „Tak, to jest gorsze niż ta bieda” (Rc/FG3); „Nie patrzą na to, czy my mamy, czy nie, tylko »Idź stąd «” (Rg/FG3); „Brak szacunku, lekceważenie” (Re/FG3); „Tak jak wcześniej mówiliśmy, kto tego nie doświadczył, ten nie wie, a w szczególności bogaty" (Rg/FG3). Dla uczestników dwu grup dyskusyjnych relacyjny wymiar ubóstwa, relacje między światem biedy a światem zamożności i dostatku, związki z osobami i instytucjami tego drugiego świata okazały się szczególnie ważnym doświadczeniem.

Zacytowane wyżej wypowiedzi to kwintesencja ujęcia relacyjnych aspektów ubóstwa, stanowiącego jeden z głównych tematów omawianego badania i stały wątek prowadzonych dyskusji. Do podjęcia tematu relacji między bogatymi i biednymi, między światem dostatku a światem biedy, skłaniały w trakcie wywiadów liczne propozycje moderatora, takie jak: sposoby wyjścia z biedy, formy i charakter pomocy, na którą może liczyć człowiek biedny, rola różnych instytucji w jego życiu czy bezpośrednie pytanie o relacje wzajemne między biednymi i bogatymi. W tej ostatniej kwestii uczestnicy dyskusji mieli wyrobione, jednakowe, ściśle sprecyzowane zdanie: są to dwa odmienne, oddzielone od siebie światy, nie rozumiejące się nawzajem. „To takie dwa światy są po prostu” (R7/FG1); „Brak wyobraźni, inne bajki, inne światy” (RB/FG3). Obok poczucia całkowitej odrębności tych dwu światów - bogatego i biednego, dzielących je nierówności i niesprawiedliwości, wywyższania się i poniżania, występują wzajemne stereotypy i uprzedzenia.

W opinii naszych rozmówców ludzie, którzy nie są biedni, odnoszą się do biednych „z pogardą taką. Jak jesteś biedna, to co ty możesz” (R4/FG1). „Człowiek czuje tą niższość wobec ludzi bogatszych, to wszystko zależy też od własnego poczucia wartości” (Ri/FG3); „My sami mamy bardzo słabe poczucie wartości poprzez status społeczny, że jesteśmy biedni, czujemy się gorsi, choć nie powinno tak być, ale tak jest, sami czujemy się gorszą kategorią ludzi” (Rc/FG3). Kontakty z przedstawicielami właściwie każdej instytucji spoza świata biedy są, jeśli nie źródłem poczucia niższości, niesprawiedliwości, upokorzenia, to na pewno ich wzmocnieniem; oceny tych kontaktów przez samych zainteresowanych są bardzo krytyczne. Złe, lekceważące traktowanie 
biedniejszych interesantów dotyczy ośrodków pomocy społecznej (R9/FG1; R1/FG1; Ra/FG3) i w ogóle urzędów: „Na pewno w urzędach dają odczuć. Facet, który przyjdzie w garniturze, pod krawatem, ogolony, załatwiać sprawę, młoda panienka czy niemłoda, jest lepiej obsługiwany niż ten, który przyjdzie z tą samą rzeczą, a wygląda biednie" (Re/FG3). Zdaniem niektórych dyskutantów księża, podobnie jak przedstawiciele innych zawodów i instytucji, „patrzą na nas z góry" (RA/FG2).

Kolejną instytucją, której przedstawiciele traktują ludzi biednych w sposób niesprawiedliwy, stronniczy i krzywdzący jest szkoła. Niesprawiedliwi nauczyciele, wywyższający się zamożni rodzice, wykluczający biedniejszych rówieśników uczniowie to zdaniem badanych codzienność polskiej szkoły, a skutkiem tego są gorsze stopnie i niechęć dzieci z biedniejszych rodzin do szkoły i do nauki. Służba zdrowia to także instytucja, gdzie zdaniem uczestników badania dochodzi do niesprawiedliwego traktowania biednych i wyróżniania bogatych. „Spotkałem się z taką sytuacją, tam, gdzie byłem trochę czasu w szpitalu i widziałem, jak traktują bogatych, a jak traktują biednych" (RB/FG2).

Policja to także instytucja, której funkcjonariusze inaczej traktują biednych, faworyzując bogatych: ,policja też się boi i patrzą, czy ustawiony, bo nie ruszać, bo zaraz będzie sprawa, zaraz nas wypieprzą, prawda? A biednemu, to byle wjebać za przeproszeniem, no i będzie siedział cicho. Taka jest prawda" (RB/FG2). Również w sklepie człowiek biednie ubrany jest podejrzany: „wystarczy, że człowiek jest gorzej ubrany, albo gorzej wygląda, wejdzie do takiego sklepu i koniec" (Rc/FG3). Zdaniem jednego z rozmówców gorsze traktowanie ludzi żyjących w ubóstwie występuje wszędzie, dotyczy każdej sfery życia i każdej instytucji: „w każdej dziedzinie życia, od urzędów, kościołów, szkół, miejsc pracy [...] Od razu odgórnie człowieka zeszmacić” (Re/FG3).

\section{POLITYCY WOBEC UBÓSTWA}

We wszystkich grupach dyskusyjnych omawiano stosunek polityków do ubóstwa. Są oni częścią tego obcego świata ludzi bogatych, z którymi porozumienie nie jest możliwe. Zdaniem badanych, politycy w ogóle nie zajmują się problemami społecznymi, w tym biedą, to ich w ogóle nie interesuje. „Zajmują się swoimi samochodami" (RG/FG2), jak zgryźliwie powiedział jeden z młodych uczestników dyskusji. „Oni byle sobie pensje podnieść, nie patrzą na to, że ludzie nie mają i robią wszystko, żeby nas zniszczyć" (RB/FG2). Wątek działania polityków na niekorzyść ludzi biednych to stały temat dyskusji. Ewentualne zainteresowanie biedą, bezrobociem, ludźmi w trudnej sytuacji ma charakter okazjonalny i zwykle 
pojawia się w trakcie kampanii wyborczych. „Po wyborach kończy się wszystko, zawsze poruszane są [podczas kampanii wyborczej] biedne osoby w tematach, ale potem od razu to się kończy" (RH/FG2). Na co dzień problemy ludzi biednych są lekceważone, a oni sami wykorzystywani. „Zrobiła im się dziura budżetowa, to z kogo zedrą pieniądze, żeby ją zakleić? Z biednych, bo oni i tak nie dostają i to dla nich bez różnicy" (RG/FG2).

Skrajny krytycyzm wobec klasy politycznej wielokrotnie pojawia się w wypowiedziach uczestników grup dyskusyjnych, m.in. znalazł wyraz w dyskusji zainicjowanej prawdziwym wydarzeniem - tragicznym wypadkiem mikrobusu, dowożącego pracowników sezonowych do zbioru jabłek, gdy zginęło osiemnaście osób. Uczestnicy dyskusji natychmiast porównali ten tragiczny wypadek z katastrofą lotniczą, w której zginęli politycy: „Ludziom pomogli? Nie. Samolot się roztrzaskał i trzeba dać dwieście pięćdziesiąt tysięcy odszkodowania. Jak dojdzie do jakiejś tragedii, masz jakiegoś psychologa? Nie masz nic. A tam jest od razu wszystko: psycholog, pomoc taka i owaka i jeszcze coś innego. I jeszcze z wypadku też się domagają kasy, jeszcze po dwieście pięćdziesiąt tysięcy" (R2/FG1). Nierówność i niesprawiedliwość odnosi się również do śmierci.

W dyskusji o relacjach między bogatymi a biednymi pada przykład dwóch polityków, posłów na Sejm jako tych, którzy nie mają pojęcia o wydatkach, więc nie są w stanie zrozumieć ludzi biednych. Posłowie ci postanowili przeżyć miesiąc za niewielką w ich mniemaniu kwotę, co wzburzyło uczestników badań: „Za 1500 zł mieli żyć, prawda ${ }^{4}$. To ludzie za 800 żyją, a oni za 1500 nie poradzili sobie. To jest banda złodziei. Ten Tupolew to powinien na Wiejską 1 spaść, to jest prawda" (Rb/FG3). Wypowiedzi na temat polityków charakteryzuje język pełen emocji, agresji, wulgaryzmów, widocznych nawet w tej niewielkiej próbce cytatów przytoczonych w niniejszym tekście.

Polityka pojawia się w wypowiedziach dyskutantów w różnych kontekstach związanych z ubóstwem i wykluczeniem społecznym. Po pierwsze, w kontekście procesów transformacji jako jednej z przyczyn ubóstwa i w porównaniach obecnych czasów z PRL-em. „Ludzie kiedyś narzekali na komunę. Że komuna jest, że nie ma nic na półkach. Dzisiaj mają wszystko na półkach, a człowiek lata za pracą i pracy nie może znaleźć" (Rg/FG3). Winne dzisiejszej biedzie i bezrobociu jest państwo, rząd, klasa polityczna, konkretni politycy, a także bogata „góra”, „,i bogaci”. „Ale ci mówię, dużo, ale to dużo to jest winy właśnie w górze. Po prostu jest wina całego systemu, rządu, ludzi tych naprawdę bardzo, ale

${ }^{4}$ Trudno powiedzieć, do czego nawiązuje rozmówca. W lutym 2004 r. dwóch posłów PO i PiS postanowiło przeżyć miesiąc za 500 złotych, przeznaczając tę kwotę wyłącznie na potrzeby bieżące, bez opłat za mieszkanie, energię itp. Pomysł ten wzbudził oburzenie ludzi, dysponujących miesięcznie znacznie mniejszymi środkami. Posłowie wykazali się zupełną nieznajomością warunków życia w biedzie. Być może to wydarzenie miał na myśli uczestnik dyskusji. 
bardzo bogatych” (Rg/FG3). Winne jest państwo, które „nie dostosowuje zarobków do cen" (Ri/FG3), wypłaca śmieszne kwoty jako zasiłki, niewystarczające na nic, w przeciwieństwie do krajów zachodnich, Niemiec czy Irlandii, znanych z opowieści krewnych i znajomych; winien tym zaniedbaniom jest rząd i wysocy urzędnicy państwowi: „A u nas co, prezydenci miast, ministrowie po 17, po 20 tys. zł miesięcznie, jakieś śmieszne dodatki, gdzie my w ogóle takiej pensji nie możemy zarobić, oni mają takie diety i takie dodatki. Paliwo, samochody, mają wszystko sponsorowane za czyje pieniądze? Podatników. Dlaczego tak się dzieje, się dziwimy, że na świecie jest krach, że ludzie głodują, jak jeden w dostatki opływa, szynkę, wędlinę wyrzuca, a drugi z chęcią by to z kosza wyjął i zjadł. Taka jest prawda. Ludzie w ogóle nie mają współczucia dla innych. Tylko, żeby się nachapać" (Rg/FG3). Polityków, podobnie jak innych przedstawicieli świata bogatego obejmuje dyskurs nierówności społecznych i niesprawiedliwości, stanowiący kolejny wątek przewijający się w wywiadach grupowych, najsilniejszy w grupie trwale bezrobotnych.

W ocenie działalności polityków akcentuje się kilka spraw: nieudolność, brak zainteresowania, niewiedzę, niedostrzeganie problemu biedy wyrażające się, po pierwsze, w „niedostosowaniu zarobków do cen” (argument ten powtarza się $\mathrm{w}$ dyskusjach kilkakrotnie), po drugie, w bardzo niskich zasiłkach, nie wystarczających na życie, w przeciwieństwie do krajów zachodnich, gdzie z zasiłków „spokojnie idzie przeżyć”, „I generalnie nawet nie pracując za ten socjał da się wyżyć” (Re/FG3). Mówi się też o złej woli polityków, wskazuje na egoizm elit politycznych, które myślą tylko o swoich interesach, o tym, żeby jak najwięcej „się nachapać”. Pod tym względem politycy są bliscy księżom, których uczestnicy badań oskarżają o obojętność wobec biedy i o zajmowanie się swoimi sprawami. Zdaniem części dyskutantów, księża nie tylko nie pomagają biednym, ale zainteresowani są zupełnie czymś innym: „Oni tak samo tylko o pieniądzach myślą” (R3/FG1); „Patrzą na nas z góry” (RA/FG2); „Moim zdaniem kościół wykorzystuje biedę” (RH/FG2); „Tak, i co tydzień w niedzielę na co innego zbierają” (RB/FG2); „Widać nawet to po księżach, czym jeżdżą” (RH/FG2); „No tak, można pomóc, ale tak jakby chodzi o ten wyzysk" (RB/FG2). Niektórzy podkreślają, że są dobrzy i pomocni księża (,są, są tacy księża, co pomagają", RB/FG2), ale generalnie należą oni do świata odległego od biedy. Nie sprzyja to zrozumieniu problemów ludzi biednych. Podsumowując ten fragment trzeba podkreślić, że uczestnicy moich badań odmawiają politykom posiadania kompetencji merytorycznych, a jednocześnie odmawia się im kompetencji etycznych.

Kolejną instytucją świata bogatych są media, które podobnie jak politycy i przedstawiciele innych instytucji nie interesują się biedą i ludźmi biednymi. Generalnie w mediach ludzie biedni są nieobecni: „sami bogaci ludzie startują" (Rg/FG3). Zdaniem badanych media pokazują biedę i biednych co najwyżej 
„ogólnie, nie na temat” (RG/FG2); „Gdzieś tam, coś tam i idziemy dalej”(Rg/FG3). Najczęściej skupiają się na wypadkach, wydarzeniach wyjątkowych, skrajnych sytuacjach (Ra/FG3), a nie na problemach społecznych; mówią o biedzie i ludziach biednych dopiero wtedy, gdy coś bardzo złego się wydarzy, gdy dojdzie do tragedii. "To wtedy trąbią, że tu się powiesił, tam się utopił, tam się zapił" (R10/FG1). Pod tym względem reakcje mediów są bliskie reakcjom urzędników, pracowników socjalnych, polityków, którzy działają dopiero wtedy, gdy zdarzy się coś strasznego. Zwykła codzienna bieda nie budzi zainteresowania i nie skłania do pomocy. Instytucje pomagają dopiero wtedy, gdy dojdzie do tragedii: „Jak ktoś sobie życie odbierze. Jak na przykład mąż żonę zabije albo matka dziecko” (R10/FG1); „Musi dojść do tragedii” (R2/FG1); „Albo jak kobieta z głodu umrze, bo nie miał kto pomóc" (R10/FG1).

Brak jest programów publicystycznych czy jakichkolwiek innych, które pokazywałyby biedę i poruszałyby problemy ludzi żyjących w trudnych warunkach. Media nie pokazują, że są biedni ludzie, „którzy uczciwie zarabiają” (RA/FG2). Rozmówcy postulują przygotowanie takich programów, choć jednocześnie są świadomi, że ludzie bogaci nie chcieliby oglądać „takich pospolitych ludzi” i że mało kto chciałby o biedzie rozmawiać (RC/FG2). Zwykła, codzienna bieda nikogo nie interesuje, jest szara, smutna, uciążliwa. Zdaniem rozmówców, w filmach czy serialach biedy w ogóle nie ma, badani nie odnajdują tam realiów swojego życia. „No bo nie ma w programach tak, żeby pokazywali, że nie mają co robić, że nie mają pracy i że ciężko jest. I też nie zarabiają po tysiąc złotych, tylko te dwa zarabiają” (R2/FG1); „Tak, czy widzieliście jakieś meble nie od kompletu, tam wszystko jest zawsze urządzone, tam nie ma zwykłych ludzi, tam są ludzie z wyższych półek" (Ra/FG3).

Są i inne przyczyny nieobecności problemu ubóstwa w mediach. Zdaniem młodych uczestników badania (FG2), dziennikarze lokalni boją się pokazywać tragiczną sytuację w ich regionie czy miejscowości, obawiają się pisać o biedzie $\mathrm{i}$ bezrobociu, bo to może zaszkodzić wizerunkowi miasta, a w rezultacie ludziom tam żyjącym ${ }^{5}$. Może zaszkodzić, gdyż na ogół bieda jest przedstawiana w kontekście zjawisk patologicznych. „Biedę się głównie wiąże z patologią, a nie, że biedni są ludzie, którzy uczciwie zarabiają. Czyli się wiąże alkoholizm, patologie właśnie z tym" (RA/FG2). Taki wizerunek biedy sprawia, że nie budzi ona współ-

${ }^{5}$ Badani podawali przykład pewnego miasta powiatowego, w którym taka sytuacja miała miejsce. Można tu przywołać przykład Łodzi i artykułu na jej temat, jaki ukazał się w prasie brytyjskiej w styczniu 2013 r. W artykule przedstawione zostały problemy społeczne miasta (migracje, odpływ ludności), związane z ubóstwem i wykluczeniem społecznym. Jak mówili łódzcy specjaliści w programach telewizyjnych, wiernie przedstawiono rzeczywistość łódzką, niemniej spowodowało to burzę medialną (a poniekąd i polityczną) na temat niszczenia wizerunku miasta, obrażania jego mieszkańców i władz. 
czucia, lecz niechęć i wstyd. Wstyd zarówno dla ludzi, jak i dla miejscowości czy instytucji. Ludzie się wstydzą biedy, nie chcą o niej mówić i to może być kolejnym powodem nieobecności tego tematu w mediach. „Ludzie się też wstydzą swojej biedy. Ja nie chcę, żeby wszyscy wiedzieli, że ja jestem biedna i nie mam na chleb. Ja jestem w tym niższa, to już później się robię mała. Inni jakoś wyżej głowę noszą, a ja niestety nie" (Rg/FG3).

\section{PODSUMOWANIE}

Badanie „Biedni o sobie” odsłoniło subiektywny wymiar ubóstwa, pokazało sposoby przeżywania i odczuwania tej sytuacji. Badani mówili o wielu różnych emocjach związanych z biedą i były to głównie emocje negatywne: wstyd, poczucie krzywdy, lekceważenia, upokorzenia, smutek, martwienie się, lęk przed przyszłością, niepewność, poczucie bycia kimś gorszym, kimś, kto się nie liczy. $\mathrm{Z}$ dyskusji, jakie wywiązały się wokół tematów wskazanych przez moderatora wyłania się obraz osamotnienia ludzi biednych, braku wsparcia i zrozumienia ze strony otoczenia oraz świadomości, że „można polegać tylko na sobie” (R4/FG1). Utrwalenie się sytuacji ubóstwa i bezrobocia oznacza stopniowe zmniejszanie się kręgu znajomych, kurczenie się otoczenia społecznego, osłabienie kontaktów, zanik więzi, niekiedy także w ramach rodziny. „Ale to jest najgorsze, że widzisz, że własna twoja rodzina odwraca się do ciebie plecami, że nikt ci nie chce pomóc. To skoro rodzina ci nie chce pomóc, to dlaczego my narzekamy na rząd, nie? Że rząd nam nie pomaga. Bo taka jest prawda” (Rg/FG3).

Odtrąceni przez rodzinę, krewnych, znajomych, źle traktowani przez pracodawcę, urzędnika, pracownika socjalnego, księdza, policjanta, lekarza, nauczyciela, sprzedawcę w sklepie; pomijani przez media, niedostrzegani przez polityków. Właściwie każdy kontakt z instytucjami czy ich przedstawicielami ujawnia lekceważenie, brak szacunku, gorsze traktowanie i buduje poczucie wykluczenia. Nie jest to dobry punkt wyjścia do poszukiwań sposobów zmiany tej niekorzystnej sytuacji.

\section{BIBLIOGRAFIA}

Danecka M. (2007), O biedzie i bezrobociu, [w:] M. Jarosz (red.), Transformacja. Elity. Spoteczeństwo, ISP PAN, Warszawa.

Krzyżanowski M. (2011), Analiza zogniskowanych wywiadów grupowych, [w:] R. Wodak, M. Krzyżanowski (red.), Jakościowa analiza dyskursu w naukach społecznych, Warszawa: Łośgraf. 
Osiatyński W. (2004), O czym nie mówiq politycy? Wywiad z Wiktorem Osiatyńskim, „Gazeta Wyborcza", 5 marca.

Tarkowska E. (2013), Biedni o biedzie, biedni o sobie, [w:] E. Tarkowska (red.), Dyskursy ubóstwa $i$ wtjkuczenia społecznego, Warszawa: Wydawnictwo IFiS PAN.

Warzywoda-Kruszyńska W. (1996), Wstęp. Bieda - temat wyparty z dyskursu politycznego, [w:] W. Warzywoda-Kruszyńska, J. Grotowska-Leder, Wielkomiejska bieda $w$ okresie transformacji, Łódź: Instytut Socjologii Uniwersytetu Łódzkiego.

Warzywoda-Kruszyńska W. (2009), Bieda w Polsce przed wstapieniem i po wstapieniu do Unii Europejskiej, [w:] E. Skotnicka-Illasiewicz (red.), 5 lat członkostwa w Unii Europejskiej w perspektywie społecznej, Warszawa: Urząd Komitetu Integracji Europejskiej.

Warzywoda-Kruszyńska W., Grotowska-Leder J. (1996), Wielkomiejska bieda w okresie transformacji, Łódź: Instytut Socjologii Uniwersytetu Łódzkiego.

Wodak R. (2011), Wstęp: badania nad dyskursem - ważne pojęcia i terminy, [w:] R. Wodak, M. Krzyżanowski (red.), Jakościowa analiza dyskursu w naukach społecznych, Warszawa: Łośgraf.

\section{Elżbieta Tarkowska}

\section{THE POOR ABOUT POLITICIANS}

(Summary)

The article presents some results of the research study „The Poor about Themselves” conducted as part of a larger project called ,The Discourses of Poverty and Social Exclusion”. It is thematically and methodologically rooted in the research "The Poverty First Hand Study" carried out by the British scholar Ruth Lister and her collaborators. As part of my project, three groups of people who live or have lived in poverty in the past discussed their ways of defining poverty, its causes and effects, their strategies for dealing with these problems, and their views on how the poor are perceived and treated by those who have not experienced poverty themselves, especially by politicians and media. The aim of the study was to learn and reconstruct reflections, opinions and feelings of people who know poverty from the inside. 